\title{
Survey of some attributes of post-agricultural lands in Polish State Forests
}

\author{
Piotr Sewerniak \\ Department of Soil Science and Landscape Management, Nicolaus Copernicus University, \\ Lwowska 1, 87-100 Toruń, Poland, \\ e-mail: sewern@umk.pl
}

\begin{abstract}
Based on materials gained in March 2015 from the Forest Data Bank the survey of some attributes (forest address including Regional Directorate of State Forest (RDSF), area in hectares, soil unit, forest site type, dominant species in a forest stand and age of the dominant species in a stand) of post-agricultural lands occurring in Polish State Forests was conducted in the paper. Distribution of post-agricultural lands in Poland by RDSF as well as the structure of soil units, forest site types, dominant tree species and the age of the species was presented and analyzed in the article.

Distribution of post-agricultural lands is not regular in regions of Poland as the highest share of such lands in the total area of State Forests was stated for a northern part of the country (RDSF in Szczecinek, Piła and Olsztyn) and the lowest for central-southern regions (RDSF in Katowice, Radom and Kraków). In spite Brunic Arenosols distinctly prevail in cover of post-agricultural lands occurring in State Forests $(65.8 \%)$ the soil unit is not the dominant one in all regions of Poland. Namely, in RDSF located in mountainous and upland areas Cambisols and Luvisols predominate. In terms of forest site types structure, mesotrophic sites clearly prevail in post-agricultural lands as two forest site types (fresh mixed coniferous forest and fresh mixed broadleaved forest) cover $62.4 \%$ of all such lands. In spite Scots pine (Pinus sylvestris L.) is the main tree species overgrowing post-agricultural soils in Polish State Forests the share of the species in young plantations established in last two decades has clearly decreased. It has resulted from appearing since 1990s an increasing importance of ecologisation of forestry in Poland what has been reflected e.g. in a distinctly increase of a share of broadleaved species in young plantations introduced on post-agricultural lands in last decades. The trend has especially pertained oak species (Quercus petraea and Q. robur) and beech (Fagus sylvatica) of which much higher share was stated for the youngest analyzed age class $(<20$ years $)$ of post-agricultural woodlands than for older forest stands.
\end{abstract}

Key words: afforestation, post-agricultural soils, forests, Poland, Forest Data Bank.

\section{Introduction}

Deforestation resulting from agricultural development was one of the most important changes in land-use occurring in past centuries (Broda 2000; Matuszkiewicz et al. 2013). In the second half of the $19^{\text {th }}$ and in the $20^{\text {th }}$ century the trend was, however, reversed. As a result of intensification of agriculture practices mainly, broad agricultural areas were afforested what especially concerned Europe (Smykała 1990; Prevosto et al. 2004; Flinn \& Vellend 2005; Matuszkiewicz et al. 2013) and eastern North America (Flinn \& Vellend
2005; D'Orangeville et al. 2008). Thus, nowadays occurrence of forests on grounds which previously were used in agriculture is common in Europe: the share of post-agricultural soils for European forests is estimated for about 50\% (Prevosto et al. 2004). The similar share could refer also to forests in Poland (Sewerniak et al. 2014) what in big part resulted from afforestation of huge areas performed after the Second World War. Forest recovery which has taken place after the War has been the most decisive factor for increasing of forest cover of Poland from 20.8\% in 1946 (Broda 2000) to 29.3\% in 2013 (GUS 2014). 
Afforestation of agricultural lands together with survival of planted post-agricultural forest stands is commonly indicated as one of the most important tasks for nowadays forestry in Poland (e.g. Bernadzki 1990; Sobczak 1990). It results not only from widespread presence of post-arable soils in Polish forests but also from occurrence of practical problems of forest management which concern sanitary conditions of forests overgrowing such soils mainly (Rykowski 1990; Gorzelak (ed.) 1999). As Scots pine (Pinus sylvestris) has been the distinctly dominant species used for afforestation since the Second World War in Poland (Smykała 1990) pine stands being introduced in huge areas on post-agricultural lands are commonly oppressed by disasters among which root-system diseases are of the highest importance for survival of forest stands (Rykowski 1990). As it was indicated in many studies (e.g. Maciaszek \& Zwydak 1996a,b; Bednarek \& Michalska 1998; Prevosto et al. 2004; Sewerniak et al. 2014) agricultural use of a soil distinctly affects its properties; thus post-agricultural pedons clearly differ from ancient forest soils and former agricultural use of a ground distinctly decreases resistance of reestablished forest stands to disasters (Szujecki 1990; Gorzelak (ed.) 1999).

Due to the high importance for forest management, the problem of post-agricultural lands occurrence in forests were widely described in literature (e.g. Bernadzki 1990; Sobczak 1990; Gorzelak (ed) 1999; Flinn \& Vellend 2005; D’Orangeville et al. 2008; Sewerniak et al. 2014). In reference to survey of attributes of post-agricultural lands in Polish forests the paper of Smykała (1990) should be primarily indicated in which the author presented some main statistics on afforested lands in Poland for the period 19451987. Taking into account high importance of post-agricultural lands occurrence for forestry, showing actual data on these lands is reasonable. Thus, the aim of this study was to present and analyze some main attributes (spatial distribution, structure of soil units and of forest site types, age and species structure of reestablished forest stands) of post-agricultural lands in Polish State Forests. The survey pertains forests administered by the State Forests National Forest Holding which manages most $(77.2 \%)$ of all forests in Poland (GUS 2014).

\section{Materials and methods}

The study was conducted based on the materials gained in March 2015 from the Forest Data Bank (www.bdl.lasy.gov. $\mathrm{pl}$ ) where detailed records on Polish forests are gathered. Resources of the Bank were filtered to obtain all single subsections of State Forests for which an occurrence of a post-agricultural soil was determined in forest inventory works. In this procedure in total 552189 subsections were obtained for the all 17 Regional Directorates of Polish
State Forests. It constituted the base for the further survey which was performed in Excel files. The following attributes for every single subsection were analyzed in the study: forest address including Regional Directorate of State Forest (RDSF), area in hectares, soil unit, forest site type, dominant species of a forest stand in overstory and actual age of the dominant species.

Soil units were determined in the source materials of the Forest Data Bank according to the Polish nomenclature used in a forest inventory (Klasyfikacja... 2000). These units were linked to the international soil classification groups (IUSS... 2014) as follows: gleby rdzawe (RD) $\rightarrow$ Brunic Arenosols (rusty soils); gleby bielicowe (B) and ochrowe (OC) $\rightarrow$ Podzols (podzolic soils and ochre soils); gleby brunatne $(\mathrm{BR})$ and gleby płowe $(\mathrm{P}) \rightarrow$ Cambisols (brown soils) and Luvisols (lessive soils) respectively; gleby gruntowoglejowe $(\mathrm{G})$, opadowoglejowe (OG) i murszowate $(\mathrm{MR}) \rightarrow$ Gleysols (gley soils and mucky soils); gleby murszowe, mułowe and torfowe $\rightarrow$ Histosols (half bog soils, mud soils and peat soils); mady rzeczne (MD) $\rightarrow$ Fluvisols (river alluvial soils). Cambisols and Luvisols were jointly analyzed in the study because truncated Luvisols were commonly classified in mapping field works performed in Poland as Cambisols (Świtoniak \& Bednarek 2014; Świtoniak et al. 2014). Division for forest site types were given in a paper according to units used in forest inventory works in Poland (Siedliskowe... 2004).

\section{Results and discussion}

\subsection{Area and spatial distribution}

The obtained in this study total area of post-agricultural lands occurring in State Forests equaled 1563.0 thousand hectares which was $22.1 \%$ of all forest cover of State Forests in Poland (Table 1). Big part of this area is constituted by grounds afforested after the Second World War. In the period 1947-1987 658.4 thousand hectares were afforested (Smykała 1990) and other ca. 150 thousand hectares of state forests have been planted on post-agricultural lands since 1990s (Kaliszewski et al. 2014). The obtained in this study value distinctly exceeds total area of post-war afforested grounds in State Forest. It must be keep in mind, however, that in this analysis all post-agricultural lands occurring in State Forests are included regardless time when soil was afforested. Thus, surely big part of indicated in this paper post-agricultural lands are those which were in agricultural use and were afforested before the Second World War.

Area and share of post-agricultural lands in a total area of forests is spatially differentiated as both values are almost regularly highest for RDSF located in north-western (Szczecinek, Piła, Szczecin) and central-northern (Olsztyn, 
Table 1. Some data on post-agricultural lands occurring in State Forests by RDSF

\begin{tabular}{|c|c|c|c|c|}
\hline Directorate & $\begin{array}{l}\text { Total area of forests } \\
\text { [thous. ha]* }\end{array}$ & $\begin{array}{c}\text { Area of post-agricultural } \\
\text { lands in forests } \\
\text { [thous. ha] }\end{array}$ & $\begin{array}{l}\text { Share of post-agricultural } \\
\text { lands in forests }[\%]\end{array}$ & $\begin{array}{c}\text { Mean age of forest } \\
\text { stands overgrowing post- } \\
\text { agricultural lands [years] }\end{array}$ \\
\hline Białystok & 573.0 & 110.3 & 19.2 & 46.0 \\
\hline Gdańsk & 284.4 & 74.7 & 26.3 & 52.5 \\
\hline Katowice & 595.5 & 22.2 & 3.7 & 39.6 \\
\hline Kraków & 167.8 & 15.7 & 9.4 & 52.2 \\
\hline Krosno & 400.0 & 103.0 & 25.8 & 50.1 \\
\hline Lublin & 392.6 & 49.9 & 12.7 & 47.2 \\
\hline Łódź & 282.7 & 60.6 & 21.4 & 50.1 \\
\hline Olsztyn & 567.9 & 186.5 & 32.8 & 52.6 \\
\hline Piła & 338.3 & 115.7 & 34.2 & 52.6 \\
\hline Poznań & 407.8 & 106.1 & 26.0 & 52.0 \\
\hline Radom & 308.5 & 21.7 & 7.0 & 44.7 \\
\hline Szczecin & 637.1 & 152.3 & 23.9 & 51.6 \\
\hline Szczecinek & 569.7 & 232.8 & 40.9 & 53.0 \\
\hline Toruń & 421.5 & 117.3 & 27.8 & 49.2 \\
\hline Warszawa & 182.5 & 32.9 & 18.0 & 50.2 \\
\hline Wrocław & 525.1 & 73.5 & 14.0 & 46.6 \\
\hline Zielona Góra & 424.7 & 87.8 & 20.7 & 54.4 \\
\hline In total & 7079.4 & 1563.0 & 22.1 & 50.7 \\
\hline
\end{tabular}

* according to GUS 2014

Gdańsk) part of Poland (Table 1). It results from historical circumstances because these regions of the country were in big part rescued and joined to Poland after the Second World War and thus there were huge areas of abandoned agricultural lands which were afforested (Smykała 1990). In general, low share of post-agricultural grounds was stated for RDSF located in mountainous and upland regions (especially RDSF in Katowice: 3.7\%, Table 1) where natural environmental conditions have been unfavorable for agricultural use. An exceptional RDSF is here the one in Krosno which in spite location in an upland and hilly region is characterized by relatively high share of post-agricultural lands $(25.5 \%$, Table 1$)$ in forests. This is also conditioned by historical circumstances as after the Second World War many villages located in south-eastern Poland were left by people and thus many hectares of abandoned agricultural lands were afforested there.

\subsection{Soil units and forest site types}

The distinctly dominant soil unit occurring in post-agricultural forests is Brunic Arenosol which covers $65.8 \%$ of all post-agricultural lands in Polish State Forests (Table 2). This must not be surprised, because as the soil is characterized by texture of loose sand mainly it is too poor in nutrients and of too low water-sorption ability for agricultural use (Bednarek \& Prusinkiewicz 1990; Bednarek \& Michalska 1998). Thus, Brunic Arenosols have been designed as the preferred soil unit for the $20^{\text {th }}$ century afforestations. However, this soil unit is not the prevailing one in post-agricultural lands of all RSDF because in two Directorates located in southern Poland (Kraków and Krosno) fine-textured soils (Cambisols and Luvisols) dominate (Fig. 1). This reflects geographical distribution of soils in Poland as in uplands and mountains of the southern part of the country Cambisols and Luvisols are soils of a very high share (Bednarek \& Prusinkiewicz 1990). It causes also that in two other RDSF located in southern Poland (Wrocław 
Table 2. Area and share of soil units for post-agricultural lands in State Forests as well as mean age of forest stands by the units

\begin{tabular}{|l|c|c|c|}
\hline Soil unit & $\begin{array}{c}\text { Area } \\
\text { [thous. ha] }\end{array}$ & $\begin{array}{c}\text { Share } \\
{[\%]}\end{array}$ & $\begin{array}{c}\text { Age } \\
\text { [years] }\end{array}$ \\
\hline Brunic Arenosols (RD)* & 1027.0 & 65.8 & 52.3 \\
\hline Podzols (B, OC) & 107.9 & 6.9 & 50.6 \\
\hline Cambisols, Luvisols (BR, P) & 266.0 & 17.1 & 50.1 \\
\hline Gleysols (G, MR, OG) & 71.0 & 4.5 & 42.3 \\
\hline Histosols (M, MŁ, T) & 11.6 & 0.7 & 37.2 \\
\hline Fluvisols (MD) & 8.5 & 0.5 & 42.0 \\
\hline other soils & 47.0 & 3.0 & 46.6 \\
\hline missing data on a soil unit & 24.0 & 1.5 & 45.8 \\
\hline
\end{tabular}

*In brackets abbreviations of soil units names used in the Polish nomenclature (Klasyfikacja... 2000) are given. and Katowice) the share of Brunic Arenosols is less than $50 \%$ while for all RDSF located in central or northern Poland the share is distinctly higher than half of all post-agricultural forest lands (Fig. 1). The highest dominance of Brunic Arenosols was found for the RDSF in Łódź (77.7\%) and in Szczecinek (76.3\%).

In terms of forest site types structure of post-agricultural lands fresh sites distinctly prevail which were stated for $92.8 \%$ of a total area of the lands in State Forests. The total share of wet as well as boggy sites was clearly lower as they covered $5.6 \%$ and $0.8 \%$ of a post-agricultural lands area, respectively. The site which clearly prevails in structure of forest site types is the fresh coniferous mixed forest (BMśw) which covers $35.9 \%$ of all post-agricultural lands in State Forests (Table 3). It reflects the distinct dominance in post-agricultural forests mesotrophic forest sites as all mixed coniferous forests (including all of their moisture variants) cover $37.3 \%$. The share of all types of mixed broadleaved forests on post-agricultural lands is slightly lower $(29.5 \%)$ while shares of the poorest (coniferous forests) as well as the most eutrophic forest sites (broadleaved forests, swamp forests and a flood plain forest) are distinctly lower: it equals $16.5 \%$ and $16.6 \%$, respectively (Table $3)$. This can be linked to the structure of soil units occurring in post-agriculture lands, namely to the distinct dom-

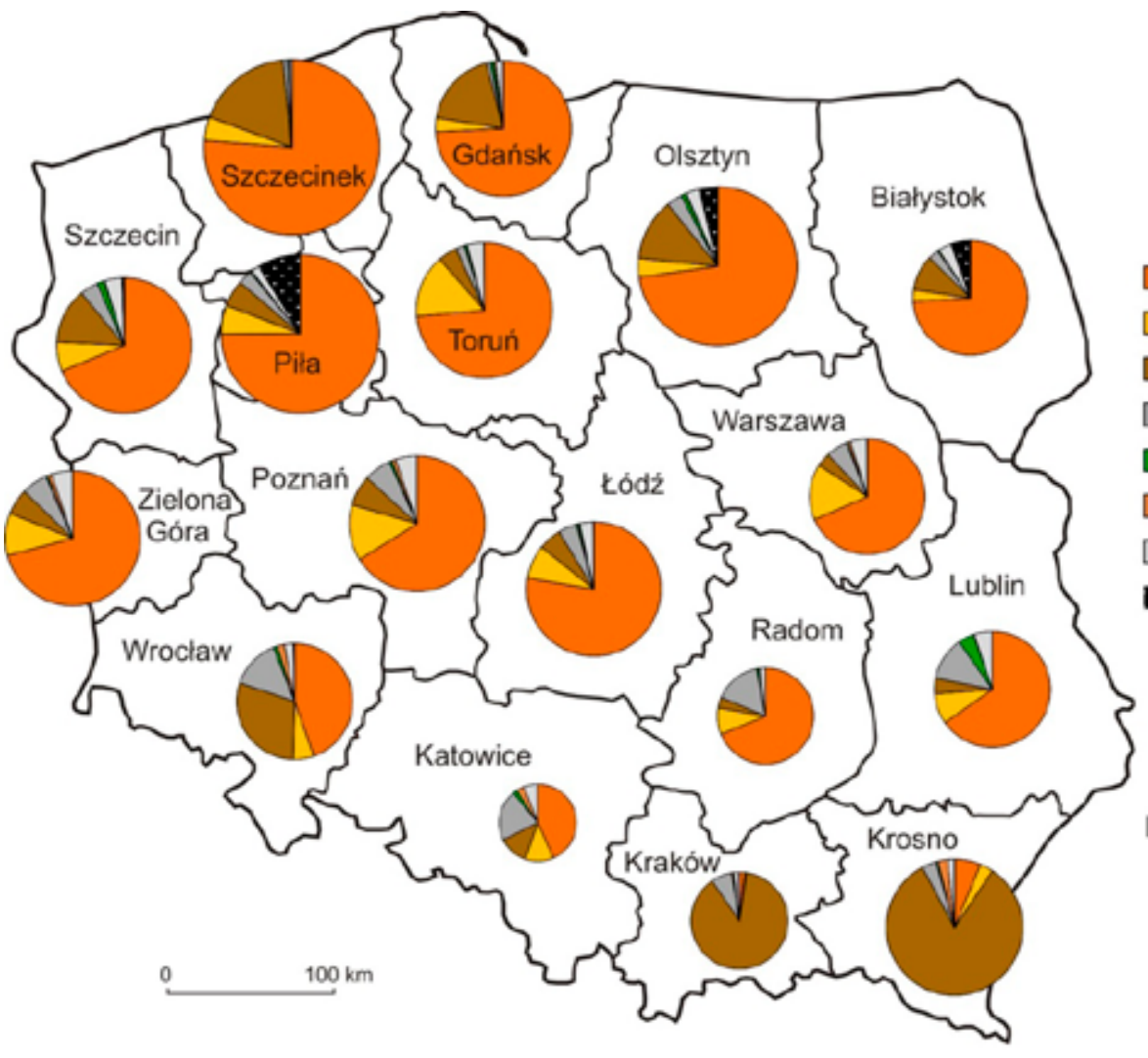

Soil units

Brunic Arenosols (RD)*

Podzols (B, OC)

Cambisols, Luvisols (BR, P:

Gleysols (G, MR, OG)

Histosols (M, Mt, T)

Fluvisols (MD)

other soils

missing data on a soil unit

Share of post-agricultural lands in forests of RDSF [\%]

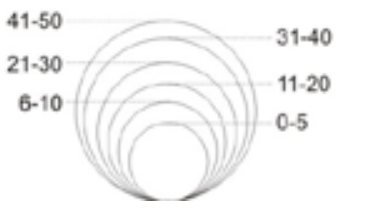

Figure 1. Share of soil units for post-agricultural forests by Regional Directorates of State Forests in Poland. *In brackets abbreviations of soil units names used in the Polish nomenclature (Klasyfikacja... 2000) are given 
Table 3. Area and share of forest site types for post-agricultural lands in State Forests as well as mean age of forest stands by the types

\begin{tabular}{|l|c|c|c|}
\hline Soil unit & $\begin{array}{c}\text { Area } \\
\text { [thous. ha] }\end{array}$ & $\begin{array}{c}\text { Share } \\
{[\%]}\end{array}$ & $\begin{array}{c}\text { Age } \\
\text { [years] }\end{array}$ \\
\hline Dry coniferous forest (Bs) & 1.7 & 0.1 & 45.8 \\
\hline Fresh coniferous forest (Bśw) & 255.5 & 16.3 & 52.2 \\
\hline $\begin{array}{l}\text { Fresh mixed coniferous forest } \\
\text { (BMśw) }\end{array}$ & 561.2 & 35.9 & 51.6 \\
\hline $\begin{array}{l}\text { Fresh mixed broadleaved forest } \\
\text { (LMśw) }\end{array}$ & 413.9 & 26.5 & 52.0 \\
\hline Fresh broadleaved forest (Lśw) & 218.3 & 14.0 & 49.8 \\
\hline Moist coniferous forest (Bw) & 1.7 & 0.1 & 49.0 \\
\hline $\begin{array}{l}\text { Moist mixed coniferous forest } \\
\text { (BMw) }\end{array}$ & 22.0 & 1.4 & 45.1 \\
\hline $\begin{array}{l}\text { Moist mixed broadleaved forest } \\
\text { (LMw) }\end{array}$ & 44.4 & 2.9 & 42.4 \\
\hline Moist broadleaved forest (Lw) & 20.9 & 1.3 & 41.8 \\
\hline Boggy coniferous forest (Bb) & 0.1 & 0.0 & 63.7 \\
\hline $\begin{array}{l}\text { Boggy mixed coniferous forest } \\
\text { (BMb) }\end{array}$ & 0.6 & 0.0 & 44.1 \\
\hline $\begin{array}{l}\text { Boggy mixed broadleaved forest } \\
\text { (LMb) }\end{array}$ & 1.9 & 0.1 & 39.0 \\
\hline Alder swamp forest (Ol) & 10.6 & 0.7 & 36.9 \\
\hline Ash-alder swamp forest (OlJ) & 3.3 & 0.2 & 36.8 \\
\hline Flood plain forest (Lł) & 6.1 & 0.4 & 41.6 \\
\hline $\begin{array}{l}\text { missing data about forest site } \\
\text { type }\end{array}$ & 0.8 & 0.1 & 50.7 \\
\hline
\end{tabular}

* In brackets abbreviations of forest site types names used in Polish nomenclature (Siedliskowe... 2004) were given

inance of Brunic Arenosols (Table 2) which usually form forest sites of medium trophic conditions (fresh mixed coniferous and fresh mixed deciduous forest mainly).

\subsection{Age and species structure of forest stands}

The averaged age of forest stands overgrowing post-agricultural lands equals 50.7 years (Table 4), however some interesting differences between taxas of trees can be noticed. The highest mean age was stated for black locust (Robinia pseudacacia) which results from historical and present trends in Polish forestry. The species was planted in Polish forests in the past, however, due to the ecologisation of forestry which has strongly appeared in Poland since
Table 4. Some characteristics of tree species structure in post-agricultural State Forests

\begin{tabular}{|l|c|c|c|}
\hline Species & $\begin{array}{r}\text { Total area } \\
\text { [thous. ha] }\end{array}$ & Share [\%] & $\begin{array}{c}\text { Mean age } \\
\text { [years] }\end{array}$ \\
\hline Pine & 1228.2 & 78.6 & 53.4 \\
\hline Larch & 21.9 & 1.4 & 37.8 \\
\hline Spruce & 53.5 & 3.4 & 42.1 \\
\hline Fir & 4.5 & 0.3 & 46.8 \\
\hline Oak & 65.5 & 4.2 & 35.9 \\
\hline Beech & 15.3 & 1.0 & 29.2 \\
\hline Birch & 92.6 & 5.9 & 49.1 \\
\hline Black locust & 2.0 & 0.1 & 57.5 \\
\hline Alder & 52.8 & 3.4 & 40.7 \\
\hline Poplar, aspen & 3.4 & 0.2 & 42.3 \\
\hline Other species & 23.3 & 1.5 & 48.0 \\
\hline In total & 1563.0 & 100.0 & 50.7 \\
\hline
\end{tabular}

1990s the species as being a foreign one for the European ancient flora, nowadays is not usually welcomed when species composition of young plantation for afforested ground is established. The reasons resulting from ecologisation of forestry can also explain higher averaged age of pine stands ( 53.4 years) in comparison to all broadleaved native species (Table 4). Until 1980s afforested lands were almost entirely overplanted with Scots pine (Pinus sylvestris) in Poland, regardless a soil unit and a forest site type (Smykała 1990); however it unfavorably influenced forest ecosystem as planted pine monocultures negatively affected not only soils (Hagen-Thorn et al. 2004; Mroziński \& Modrzyński 2006; Sewerniak et al. 2014) but also species composition of ground vegetation (Laska 2006, 2014; Matuszkiewicz et al. 2013). The situation has changed since 1990s when ecologisation trends have clearly appeared in Polish forestry (Zielony 2001). It has been manifested for example in an increase care to restore compatibility between real and potential vegetation (Balcerkiewicz 2001) what was reflected in higher share of broadleaved species (oak and beech mainly) in young plantations established on post-agricultural lands. This trend is clearly seen when post-agricultural forests are investigated with regard to the age of a forest stand. As it can be seen from the figure 2 the share of coniferous species is distinctly lower for the youngest age class $(<20$ years) than for older stands what results from reduced participation of pine and spruce mainly. From the other hand share of oak and beech is clearly the highest for the youngest class (Fig. 2). It has 


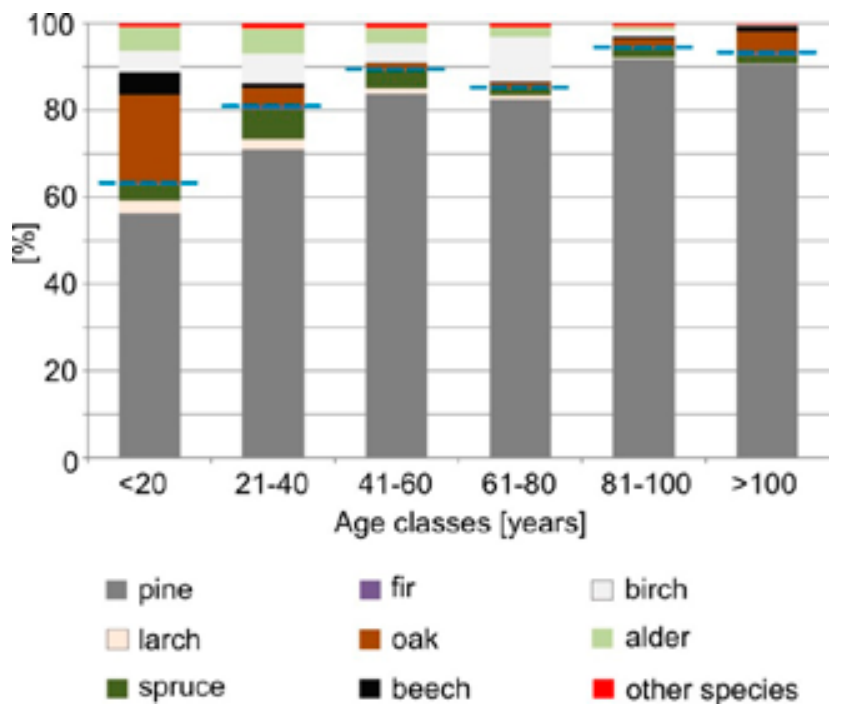

Figure 2. Share of tree species in stands overgrowing post-agricultural lands in State Forests by age classes. Horizontal dotted lines separate total shares of coniferons and broadleared species

a decisive contribution to the fact that for the period of the last 20 years a total share of broadleaved species in young plantations established on post-agricultural lands equaled $37 \%$ while the share calculated for previous decades oscillated about one third of this value (Fig. 2).

It should be keep in mind, however, that averaged ages of forest stands given in this paper to some extent are influenced by methodological problems which concern defining soils as post-agricultural pedons in field works. Namely, in forest inventory works post-agricultural past of a soil is defined first of all based on occurrence of a ploughing horizon in morphology of a soil. However, in soils of high biological activity and of a deep humus horizon the visual occurrence of a ploughing layer in soil morphology disappears much faster in time than in other soils. That is why it is necessary to be aware that designation of some fertile/ wet/boggy soils which were overgrown by old-growth forests when forest inventory works were done as post-agricultural pedons could be omitted. As a result, mean ages of forest stands as well as post-agricultural area given in this article for some soil units (Histosols and Gleysols mainly) and forest site types (boggy and swamp sites primarily) could be understated. It concerns also averaged age of tree species overgrowing soils which are usually characterized by high biological activity and a deep humus horizon. In the main it refers to black alder (Alnus glutinosa) which commonly overgrows such soils.

\section{Conclusions}

Distribution of post-agricultural lands in Polish forests is not regular what is caused by historical and environmental circumstances mainly. The highest share of such lands occurs in northern regions while the lowest in central-southern Poland. In the forest site types structure mesotrophic sites clearly prevail in post-agricultural lands of Polish State Forests and the dominant soils for the lands are Brunic Arenosols. In spite the natural vegetation of the soils are broadleaved forests (Biały 1999, 2008; Jankowski 2014 ) for most decades of the $20^{\text {th }}$ century Scots pine ( $P i$ nus sylvestris) was the distinctly preferred species used for afforestations in Poland regardless an occurring soil type. Thus, in the past pine monocultures were planted on huge areas of post-agricultural Brunic Arenosols. The situation has clearly changed since 1990s when ecologisation trends have distinctly appeared in Polish Forestry. As a result, in nowadays afforestations the share of introduced broadleaved species is much higher than it was before.

\section{Acknowledgments}

The author is grateful to workers of the Forest Data Bank for sharing and preparing the basic material for this study.

\section{References}

Balcerkiewicz S., 2001, Ocena zgodności fitocenozy z biotopem z punktu widzenia botaniki [Assessment of compatibility between phytocoenosis and biotope from botanical point of view], [in:] R. Zielony (ed.), Zgodność fitocenozy z biotopem w ekosysyemach leśnych [Compatibility between phytocoenosis and biotope in forest ecosystems], Fund. Rozwój SGGW, Warszawa: 22-33.

Bednarek R. \& Michalska M., 1998, Wpływ rolniczego użytkowania na morfologię i właściwości gleb rdzawych w okolicach Bachotka na Pojezierzu Brodnickim [Effect of agricultural use on morphology and properties of rusty soils in the surroundings of Bachotek Lake in the Brodnica Lakeland], Zesz. Probl. Post. Nauk Roln. 460: 487-497.

Bednarek R. \& Prusinkiewicz Z., 1990, Geografia gleb [Soil geography], PWN, Warszawa.

Bernadzki Z., 1990, Koncepcje hodowli lasu na gruntach porolnych [Concepts of silviculture on post-agricultural lands], Sylwan 134: 51-59.

Biały K., 1999, Dowolność wyróżniania typów siedliskowych lasu i projektowania składów docelowych drzewostanów w obrębie gleb bielicoziemnych [Inconsistency in discrimination of forest site types and planning 
final species compositions in stands on podzolic soils], Sylwan 143: 65-72.

Biały K., 2008, Niedoskonałości typologii leśnej stosowanej w lasach niżowych Polski i ich ekologiczne skutki [Deficiencies of forest typology used for lowland Polish forests and their ecological consequences], [in:] S. Mazur, H. Tracz (eds), Zagrożenia ekosystemów leśnych przez człowieka. Rozpoznanie, monitoring, dzialanie [Anthropogenic hazards in forests. Recognition, monitoring, activity], Wyd. SGGW, Warszawa: 67-75.

Broda J., 2000, Historia leśnictwa w Polsce [History of forestry in Poland], Wyd. AR im. A. Cieszkowskiego w Poznaniu, Poznań.

D’Orangeville L., Bouchard A. \& Cogliastro A., 2008, Post-agricultural forests: Landscape patterns add to stand-scale factors in causing insufficient hardwood regeneration, For. Ecol. Manage. 255: 1637-1646.

Flinn K.M. \& Vellend M., 2005, Recovery of forest plant communities in post-agricultural landscapes. Frontiers in Ecol. and the Environment 3: 243-250.

Gorzelak A. (ed.), 1999, Zalesianie gruntów porolnych [Afforestation of post-agricultural lands], Instytut Badawczy Leśnictwa, Warszawa.

Główny Urząd Statystyczny. Leśnictwo 2014 [Central Statistical Office. Forestry 2014], Warszawa 2014.

Hagen-Thorn A., Callesen I., Armolaitis K. \& Nihlgård B., 2004, The impact of six Euro-pean tree species on the chemistry of mineral topsoil in forest plantations on former ag-ricultural land, For. Ecol. Manage. 195: 373-384

IUSS Working Group WRB. World Reference Base for Soil Resources, 2014, International soil classification system for naming soils and creating legends for soil maps, World Soil Resources Reports No. 106. FAO, Rome.

Jankowski M., 2014, Bielicowanie jako wtórny proces w glebach rdzawych Brodnickiego Parku Krajobrazowego [Podzolization as a secondary process in rusty soils of the Brodnica Landscape Park], [in:] M. Świtoniak, M. Jankowski, R. Bednarek (eds), Antropogeniczne przekształcenia pokrywy glebowej Brodnickiego Parku Krajobrazowego [Anthropogenic transformations of soil cover in the Brodnica Landscape Park], Wyd. Nauk. UMK, Toruń: 9-24.

Kaliszewski A., Wysocka-Fijorek E., Jabłoński M. \& Młynarski W., 2014, Aktualizacja Krajowego Programu Zwiększania Lesistości. Synteza [Actualisation of the National Programme of Forest Cover Increase. Synthesis], IBL, Sękocin Stary.

Klasyfikacja gleb leśnych Polski [Classification of forest soils of Poland], 2000, CILP, Warszawa.

Łaska G., 2006, Tendencje dynamiczne zbiorowisk zastępczych w Puszczy Knyszyńskiej [Dynamic tendencies of the secondary communities in the Knyszyńska Forest], Bogucki Wyd. Nauk., Białystok-Poznań.

Łaska G., 2014, Ecological consequences of deforestation and afforestation on a post-arable land: Changes in the composition and structure of plant communities and transformations of oak-hornbeam habitats and soil, Ecological Questions 20: 9-21.

Maciaszek W. \& Zwydak M., 1996a, Przekształcanie górskich gleb porolnych przez przed-plony sosnowe. Część I. Przemiany morfologii profilu i właściwości fizycznych gleb [Transformation of mountain postagricultural soils by pioneer pine stands. Part I. Changes in the profile morphology and physical properties of soils], Acta Agr. et Silv., ser. Silv. 34: 67-80.

Maciaszek W. \& Zwydak M., 1996b, Przekształcanie górskich gleb porolnych przez przed-plony sosnowe. Część II. Przemiany właściwości chemicznych gleb [Transformation of mountain postagricultural soils by pioneer pine stands. Part II. Changes in the chemical properties of soils], Acta Agr. et Silv., ser. Silv. 34: 8192.

Matuszkiewicz J.M., Kowalska A., Kozłowska A., Roo-Zielińska E. \& Solon J., 2013, Differences in plant-species composition, richness and community structure in ancient and post-agricultural pine forests in central Poland, For. Ecol. Manage. 310: 567-576.

Mroziński P. \& Modrzyński J., 2006, Właściwości gleby pod okapem czterech gatunków drzew leśnych po 30 latach od ich posadzenia na dwóch różnych siedliskach [Soil properties under the canopy of four forest tree species 30 years after planting on two different forest sites], Sylwan 105: 26-37.

Prevosto B., Dambrine E., Moares C. \& Curt T., 2004, Effect of volcanic ash and former agri-cultural use on the soil and vegetation of naturally regenerated woodlands in the Massif Central, France, Catena 56: 239-261.

Rykowski K., 1990, Problemy ochrony lasu na gruntach porolnych [Problems of forest protection on afforested agricultural grounds], Sylwan 134: 75-88.

Sewerniak P., Sylwestrzak K., Bednarek R. \& Gonet S., 2014, Gleby porolne w lasach [Post-agricultural soils in forests], [in:] M. Świtoniak, M. Jankowski, R. Bednarek (eds), Antropogeniczne przekształcenia pokrywy glebowej Brodnickiego Parku Krajobrazowego [Anthropogenic transformations of a soil cover in the Brodnica Landscape Park], Wyd. Nauk. UMK, Toruń: 43-55.

Siedliskowe podstawy hodowli lasu [Forest site basics of silviculture], 2004, ORW LP w Bedoniu, Warszawa.

Smykała J., 1990, Historia, rozmiar i rozmieszczenie zalesień gruntów porolnych w Polsce w latach 19451987 [History, area and distribution of afforestation of post-agricultural lands in Poland in the years 19451987], Sylwan 134: 1-7. 
Sobczak R., 1990, Teoretyczne i praktyczne aspekty zakładania upraw i prowadzenia drzewo-stanów na gruntach porolnych [Theoretical and practical aspects of establishment of plantations and silvicultural proceeding in stands on post-agricultural lands], Sylwan 134: 61-74.

Szujecki A., 1990, Ekologiczne aspekty odtwarzania ekosystemów leśnych na gruntach porolnych [Ecological aspects of redevelopment of forest ecosystems on old farm land], Sylwan 134: 23-40.

Świtoniak M. \& Bednarek R., 2014, Denudacja antropogeniczna [Anthropogenic denudation], [in:] M. Świtoniak, M. Jankowski, R. Bednarek (eds), Antropogeniczne przekształcenia pokrywy glebowej Brodnickiego Parku Krajobrazowego [Anthropogenic transforma- tions of a soil cover in the Brodnica Landscape Park], Wyd. Nauk. UMK, Toruń: 57-84.

Świtoniak M., Mroczek P. \& Bednarek R., 2014, Luvisols or Cambisols? Micromorphological study of soil truncation in young morainic landscapes - Case study: Brodnica and Chełmno Lake Districts (North Poland), Catena (in press).

Zielony R., 2001, Uwarunkowania siedliskowe gospodarki leśnej u progu XXI wieku - zarys problem [Site conditions of forest management at the turn of the XX and XXI centuries - outline of the problem], [in:] R. Zielony (ed.), Zgodność fitocenozy z biotopem w ekosysyemach leśnych [Compatibility between phytocoenosis and biotope in forest ecosystems], Fund. Rozwój SGGW, Warszawa: 6-8. 